\title{
Antioxidant and Tyrosinase Inhibitory Properties of an Aqueous Extract of Garcinia atroviridis Griff. ex. T. Anderson Fruit Pericarps
}

\author{
Moragot Chatatikun 1,2,3, Pitaksit Supjaroen', Patcharaporn Promlat', Chantanapa Chantarangkul', Sutida \\ Waranuntakul' ${ }^{\text {, Jiraphat Nawarat }}{ }^{4}$, Jitbanjong Tangpong ${ }^{1,2,3}$, Anchalee Chiabchalard ${ }^{5, *}$
}

\author{
Moragot Chatatikun ${ }^{1,2,3}$, Pitaksit \\ Supjaroen ${ }^{1}$, Patcharaporn \\ Promlat ${ }^{1}$, Chantanapa \\ Chantarangkul' ${ }^{\text {, Sutida }}$ \\ Waranuntakul', Jiraphat \\ Nawarat ${ }^{4}$, Jitbanjong \\ Tangpong ${ }^{1,2,3}$, Anchalee \\ Chiabchalard ${ }^{5, *}$
}

'Department of Medical Technology, School of Allied Health Sciences, Walailak University, Nakhon Si Thammarat 80161, THAILAND.

${ }^{2}$ Research Excellence Center for Innovation and Health Product, Walailak University, Nakhon Si Thammarat 80161, THAILAND.

${ }^{3}$ Center of Excellence Research for Meliodosis (CERM), Walailak University, Nakhon Si Thammarat 80161, THAILAND.

${ }^{4}$ Division of Physical Therapy, School of Allied Health Sciences, Walailak University, Nakhon Si Thammarat 80161, THAILAND.

${ }^{5}$ Department of Clinical Chemistry, Faculty

of Allied Health Sciences, Chulalongkorn

University, Bangkok 10330, THAILAND.

\section{Correspondence}

\section{Anchalee Chiabchalard}

Department of Clinical Chemistry, Faculty of Allied Health Sciences, Chulalongkorn University, Bangkok 10330, THAILAND.

Phone no: +66-2218-1065

E-mail: anchalee.c@chula.ac.th

History

- Submission Date: 29-10-2019

- Review completed: 11-11-2019;

- Accepted Date: 14-11-2019.

DOI : 10.5530/pj.2020.12.12

Article Available online

http://www.phcogj.com/v12/i1

\section{Copyright}

(C) 2020 Phcogj.Com. This is an openaccess article distributed under the terms of the Creative Commons Attribution 4.0 International license.

\section{ABSTRACT}

Background: Ultraviolet radiation (UVR) is the major cause for hyperpigmentation, and to prevent this natural products are increasingly being explored as potential skin whitening agents. The aim of this study was to determine the total phenolic and flavonoid content, free radical scavenging activity, anti-tyrosinase activity and the inhibition of melanin content in $\alpha$-melanocyte stimulating hormone-induced B16F10 melanoma cells of an aqueous extract of Garcinia atroviridis Griff. ex. T. Anderson fruit pericarps. Methods: The aqueous extract was prepared by extraction with distilled water at $105^{\circ} \mathrm{C}$ for $60 \mathrm{~min}$. Total phenolic and flavonoid content were determined using the Folin-Ciocalteau and aluminium chloride methods, respectively. Scavenging activity was assessed using 2,2-Diphennyl-1-picrylhydrazyl (DPPH) and 2,2'-Azino-bis(3-ethylbenzothiazoline-6-sulfonic acid) diammonium salt (ABTS). Tyrosinase activity and melanin content were determined spectrophotometrically. Results: The results showed that the aqueous extract of Garcinia atroviridis fruit pericarps had a phenolic (26.33 $\pm 0.77 \mathrm{mg} \mathrm{GAE} / \mathrm{g}$ plant extract) and flavonoid content (9.31 $\pm 0.40 \mathrm{mg}$ QE/g plant extract). The aqueous extract of Garcinia atroviridis significantly inhibited mushroom tyrosinase activity $\left(I C_{50}\right.$ of $40.72 \pm 1.83 \mu \mathrm{g} / \mathrm{mL}$ ) and cellular tyrosinase activity (at a concentration of $125 \mu \mathrm{g} / \mathrm{mL}$ ) in $\alpha$-melanocyte stimulating hormone-induced B16F10 melanoma cells. The Garcinia atroviridis extract also suppressed melanin content at concentrations of $31.25-125 \mu \mathrm{g} / \mathrm{mL}$. Correlations of mushroom tyrosinase inhibition with DPPH and ABTS scavenging activities were 0.8673 and 0.9468 , respectively. Conclusion: Our findings show that an aqueous extract of Garcinia atroviridis fruit pericarps is a source of natural compounds and antioxidant capacity which can inhibit tyrosinase activity and melanin content. Thus, aqueous extracts of Garcinia atroviridis may be a potential source of skin whitening agents for hyperpigmentation.

Key words: Garcinia atroviridis, Tyrosinase activity, Melanin, a-MSH, B16F10 cells.

\section{INTRODUCTION}

Ultraviolet radiation (UVR) is an external factor for skin disorders including tanning, hyperpigmentation, cancer and immunomodulation. ${ }^{1}$ Repeated exposure to suberythemal UV irradiation activates melanin synthesis which results in increased melanin content in human skin. ${ }^{2} \mathrm{UV}$ also induces oxidative stress through the production of reactive oxygen species (ROS), which induces DNA damage in keratinocytes and activates p53. ${ }^{3}$ Then, p53 stimulates opiomelanocortin (POMC) gene expression, the product of which is cleaved to produce $\alpha$-melanocyte stimulating hormone ( $\alpha-\mathrm{MSH})$, adrenocorticotropic hormone and $\beta$-endorphin. ${ }^{4}$ In turn $\alpha$-MSH induces the upregulation of tyrosinase enzyme which is the rate limiting enzyme for melanin synthesis in melanocytes. ${ }^{5}$ Thus, tyrosinase is a target for melanogenesis inhibition. In addition, free radical scavenging activity is also a desirable property for skin whitening agents. ${ }^{6}$

Phenolic and flavonoid compounds have the capacity to protect against UV induced DNA damage in keratinocytes. Moreover, as phenolic and flavonoid compounds have a structure similar to tyrosine, which is a substrate for melanin, they can directly inhibit tyrosinase activity. ${ }^{7}$ Nowadays, there are many well characterized tyrosinase inhibitors such as hydroquinone, arbutin, kojic acid, azelaic acid and L-ascorbic acid. ${ }^{8}$ While hydroquinone is the most popular agent for treating hyperpigmentation as it can inhibit tyrosinase activity, it has many adverse effects including skin irritation, toxicity, mutagenicity, carcinogenicity and exogenous ochronosis. ${ }^{9,10}$ Thus, many researchers have focused on botanical and natural ingredients as alternative depigmenting agents which are safe and have efficacy. ${ }^{11}$

Garcinia atroviridis Griff. ex. T. Anders (common name asam gelugur), belonging to the family Clusiaceae is commonly grown in Asian countries including Thailand, Malaysia and Indonesia. The fruits are yellowish green to yellow and globular in shape, and are commonly used as a flavouring agent in food. In Thailand, dried fruits are mixed in the popular local dish, Tom-Yum soup. In folk medicine, fruits of Garcinia atroviridis are used as pre- and postpartum medication for treating stomachache during pregnancy and as a lotion for rubbing on women's abdomen after confinement. ${ }^{12}$

Cite this article: Chatatikun M, Supjaroen P, Promlat P, Chantarangkul C, Waranuntakul S, Nawarat $\mathrm{J}$, et al. Antioxidant and Tyrosinase Inhibitory Properties of an Aqueous Extract of Garcinia atroviridis Griff. ex. T. Anderson Fruit Pericarps. Pharmacog J. 2020;12(1):71-8. 
Methanol crude extracts of leaves, fruits, roots, stem and trunk barks of Garcinia atroviridis have antioxidant, antibacterial, antifungal and antitumor activities. ${ }^{13}$ Ethyl acetate and ethanol crude extracts of fruits also have antibacterial activity. ${ }^{14}$ Aqueous extracts of fruits have noncytotoxic effects on human skin fibroblasts and have antifungal ${ }^{15}$, and antihyperlipidemic activity ${ }^{16,17}$ and inhibit acetylcholinesterase. ${ }^{18}$

However, there are no reports on the inhibition of tyrosinase activity. In this study, we aimed to determine the total phenolic and flavonoid content, free radical scavenging activity, anti-tysoinase activity and the ability to inhibit melanin content in $\alpha-\mathrm{MSH}$ induced B16F10 melanoma cells of aqueous extract of Garcinia atroviridis Griff. ex. T. Anders fruit pericarps. The findings from this study will be useful for application and development of skin whitening agents.

\section{MATERIALS AND METHODS}

\section{Materials}

2,2-Diphennyl-1-picrylhydrazyl

(DPPH), 2,2'-Azino-bis(3ethylbenzothiazoline-6-sulfonic acid) diammonium salt (ABTS), aluminium chloride $\left(\mathrm{AlCl}_{3}\right)$, Folin-Ciocalteu reagent, gallic acid, kojic acid, L-DOPA, sodium carbonate $\left(\mathrm{Na}_{2} \mathrm{CO}_{3}\right), \mathrm{NaOH}$, quercetin, Triton X-100 and mushroom tyrosinase were purchased from Sigma (St. Louis, MO). Dulbecco's modified Eagle's medium (DMEM), phosphate buffer saline (PBS) and trypsin/EDTA were obtained from Thermo Scientific Hyclone (Logan, Utah). 3-(4,5-dimethylthiazol-2yl)-2,5-diphenyltetrazolium bromide (MTT), penicillin/streptomycin and fetal bovine serum were purchased from Merck (Darmstadt, Germany). Melanocyte stimulating hormone was purchased from Abcam (Cambridge, UK).

\section{Plant materials}

Fruit pericarps of Garcinia atroviridis Griff. ex. T. Anderson were collected from Thasala, Nakhon Si Thammarat, Thailand. A voucher number was identified and collected at Department of Botany, Faculty of Science, Chulalongkorn University, Thailand with a herbarium number 016443.

\section{Plant extraction}

Fruit pericarps of dried plant material (125 g) were blended and mixed with water $(12.5 \mathrm{~L})$. The mixture was aliquoted into duran bottles $\left(1 \mathrm{~L} /\right.$ bottle). Extraction was performed at $105^{\circ} \mathrm{C}, 15$ psi for $60 \mathrm{~min}$ in autoclave. After that, the bottle was cooled down to room temperature. The mixture was filtered through Whatman No.1 filter paper (Whatman International Ltd., Kent, UK), and the filtrates were then lyophilized. The extracts were dissolved in dimethyl sulfoxide at a stock concentration of $100 \mathrm{mg} / \mathrm{mL}$ and stored at $-20^{\circ} \mathrm{C}$ until analyses. The extract yield of Garcinia atroviridis was $7.39 \pm 1.69 \%$ (w/w).

\section{Total phenolic content}

The Folin-Ciocalteu method was chosen to determine total phenolic content as described previously. ${ }^{19}$ Briefly, a stock concentration of Garcinia atroviridis Griff. Ex. T. Anderson aqueous extract (GA) was diluted in distilled water to give a concentration of $1 \mathrm{mg} / \mathrm{mL}$. Then $100 \mu \mathrm{L}$ of $0.1 \mathrm{M} \mathrm{Na}_{2} \mathrm{CO}_{3}$ solution and $100 \mu \mathrm{L}$ of $10 \%$ Folin-Ciocalteu reagent were mixed in a well of a 96-well plate. The reaction mixture was incubated for $1 \mathrm{~h}$ at room temperature. After incubation, the absorbance was measured at $750 \mathrm{~nm}$. A standard curve was plotted using gallic acid (concentration range from 1.569-200 $\mu \mathrm{g} / \mathrm{mL}$. Total phenolic content was determined as gallic acid equivalents (GAE) in mg per $1 \mathrm{~g}$ of dry plant extract.

\section{Total flavoniod content}

Total flavonoid content of the GA extract was performed as described by others. ${ }^{20}$ Briefly, $100 \mu \mathrm{L}$ of extract $(\mathrm{mg} / \mathrm{mL})$ or quercetin $(1.56-100$ $\mu \mathrm{g} / \mathrm{mL}$ ) was incubated with $100 \mu \mathrm{L}$ of $2 \% \mathrm{AlCl}_{3}$ solution in methanol for $30 \mathrm{~min}$ at room temperature. The absorbance was measured at $415 \mathrm{~nm}$ against a blank. The resultant values were determined as mg quercetin equivalents $(\mathrm{QE})$ per $1 \mathrm{~g}$ of dry plant extract.

\section{2,2-Diphennyl-1-picrylhydrazyl (DPPH) radical scavenging activity}

Free radical scavenging activity of the GA extract was determined according to the procedure previously described by others. ${ }^{21}$ Briefly, $20 \mu \mathrm{L}$ of GA extract or ascorbic acid in ethanol was added to $180 \mu \mathrm{L}$ of DPPH solution which was prepared daily. The mixture was shaken and left to stand at room temperature in the dark. After $30 \mathrm{~min}$, the absorbance was measured at $517 \mathrm{~nm}$ against a blank. Assays were done in triplicate. The DPPH scavenging activity was estimated using the equation: \%Scavenging activity $=100 \mathrm{x}$ (Abs of control - (Abs of sample - Abs of blank))/Abs of control. $\mathrm{IC}_{50}$, the concentration giving $50 \%$ inhibition of DPPH, was determined from a graph of free radical scavenging activity.

\section{$\mathrm{ABTS}^{+}$radical scavenging activity}

Free radical scavenging activity of extract was estimated by ABTS decolorization assay. ${ }^{22}$ ABTS $^{+}$was produced by mixing $7 \mathrm{mM}$ ABTS and $2.45 \mathrm{mM}$ potassium sulfate at a ratio of $2: 3 \mathrm{v} / \mathrm{v}$, and storage in the dark at room temperature for $12-16 \mathrm{~h}$ until analysis. The ABTS.+ ${ }^{+}$reagent was further diluted with methanol to reach an absorbance between $0.70 \pm 0.02$. After adding $20 \mu \mathrm{L}$ of extract or ascorbic acid and $180 \mu \mathrm{L}$ of $\mathrm{ABTS}^{+}$reagent, the mixture was measured at $45 \mathrm{~min}$ after mixing. Analysis was carried out at least three times. The percent inhibition of absorbance at $734 \mathrm{~nm}$ was calculated using the formula: \%Scavenging activity $=100 \times$ (Abs of control - (Abs of sample - Abs of blank))/ Abs of control. IC $_{50}$ was determined as the concentration giving $50 \%$ inhibition of ABTS $^{+}$.

\section{Mushroom tyrosinase activity}

Dopachrome formation in the oxidation of L-DOPA by mushroom tyrosinase activity was measured spectrophotometrically as described previously. ${ }^{19}$ The reaction mixture contained $20 \mu \mathrm{L}$ of extract or kojic acid, $20 \mu \mathrm{l}$ of mushroom tyrosinase $(203 \mathrm{U} / \mathrm{mL})$ and $160 \mu \mathrm{l}$ of $20 \mathrm{mM}$ phosphate buffer. The mixture was pre-incubated at room temperature for $10 \mathrm{~min}$. After $10 \mathrm{~min}, 20 \mu \mathrm{L}$ of $2.5 \mathrm{mM} \mathrm{L}$-DOPA was added into the mixture and the reaction was incubated for $60 \mathrm{~min}$. Kojic acid served as a positive control. Each experiment was performed in triplicate. The percent of mushroom tyrosinase activity at $475 \mathrm{~nm}$ was estimated using the formula: $100 \times$ [(Abs of sample - Abs of sample blank)]/[(Abs of control - Abs of control blank)]. The results were compared with the control group. $\mathrm{IC}_{50}$ is the concentration giving $50 \%$ of inhibition of mushroom tyrosinase activity.

\section{Cell culture}

B16F10 mouse melanoma cells (CRL-6475) were obtained from The American Type culture collection (ATCC, Rockville, MD). The cells were grown in Dulbecco's modified Eagle's medium supplemented with $10 \%$ fetal bovine serum and $1 \%$ penicillin $(100 \mathrm{U} / \mathrm{mL}) /$ streptomycin $(100 \mu \mathrm{g} / \mathrm{mL})$ at $37^{\circ} \mathrm{C}$ in a humidified atmosphere with $5 \% \mathrm{CO}_{2}$.

\section{Cell viability}

Cell viability was determined using 3-(4,5-dimethylthiazol-2-yl)-2,5diphenyltetrazolium bromide (MTT). In brief, $5 \times 10^{3}$ cells/well were seeded into a 96-well plate. After $24 \mathrm{~h}$, the cells were incubated in the presence of $1 \mu \mathrm{M} \alpha$-MSH and treated with aqueous GA extract (7.8$1000 \mu \mathrm{g} / \mathrm{mL})$ or kojic acid $(500 \mu \mathrm{g} / \mathrm{mL})$. After $48 \mathrm{~h}$, the MTT solution was added into each well. The absorbance of wells was read at $550 \mathrm{~nm}$ 
using microplate reader (Biotek, Winooski, USA). Each experiment was performed in triplicate. The percentage of cell viability was determined relative to the control.

\section{Cell tyrosinase activity assay}

The oxidation of L-DOPA to dopachrome was determined by spectrophotometry as an indicator of cellular tyrosinase activity. ${ }^{23}$ B16F10 cells ( $1 \times 10^{5}$ cells/well) were plated into each well of a 6 -well plate for $24 \mathrm{~h}$. After treatment with $1 \mu \mathrm{M} \alpha-\mathrm{MSH}$ and GA extract or kojic acid, the cells were washed twice with $100 \mathrm{mM}$ sodium phosphate buffer saline and lysed cells with $1 \%$ Triton X-100 in PBS. A total of $100 \mu \mathrm{L}$ of each lysate $(40 \mu \mathrm{g})$ was mixed with $100 \mu \mathrm{L}$ of $5 \mathrm{mM} \mathrm{L}$-DOPA solution in a 96-well plate and incubated at $37^{\circ} \mathrm{C}$ for $1 \mathrm{~h}$. The absorbance at $475 \mathrm{~nm}$ reflected the production of dopachrome. The cellular tyrosinase activity of each lysate was compared with $\alpha-\mathrm{MSH}$ treated cells.

\section{Determination of melanin content}

B16F10 cells were cultured at a density of $1 \times 10^{5}$ cells/well in a 6 -well plate. After $24 \mathrm{~h}$, the cells were treated with $1 \mu \mathrm{M} \alpha-\mathrm{MSH}$ and GA extract or kojic acid for $48 \mathrm{~h}$. After incubation, the cells were washed with phosphate buffer saline twice and collected using trypsin. The cell pellets were solubilized in $1 \mathrm{M} \mathrm{NaOH}$ at $80^{\circ} \mathrm{C}$ for $1 \mathrm{~h}$. The melanin content was determined at by absorbance at $475 \mathrm{~nm}$ and calculated from a standard curve of melanin. The percentage of melanin was calculated relative to control cells (treated with only $\alpha-\mathrm{MSH}$ ).

\section{Statistical analysis}

All results of experiments are presented as the mean \pm standard error of the means (SEM). Statistical analyses were performed using one-way ANOVA with Dunnett's post-hoc test. $P$-values less than $(P<0.05)$ were considered statistically significant. Correlations between free radical scavenging activity and tyrosinase inhibition were analyzed using the Pearson's method.

\section{RESULTS}

\section{Total phenolic and flavonoid contents}

Total phenolic content of an aqueous extract of fruit pericarp of Garcinia atroviridis (GA) was determined using a calibration curve of gallic acid, where $\mathrm{y}=0.1023 \mathrm{x}-0.0691, \mathrm{R}^{2}=0.9954$, where $\mathrm{Y}$ is an absorbance and $\mathrm{X}$ is amount of gallic acid in $\mu \mathrm{g}$. The Folin-Ciocalteu method showed that the total phenolic content in GA was $26.33 \pm 0.77$ mg GAE/g dry plant extract.

The total flavonoid content of GA was determined from a calibration curve of quercetin $(y=0.1739 x, R=0.9997)(1.56-100 \mu \mathrm{g} / \mathrm{mL})$ where $\mathrm{Y}$ is an absorbance and $\mathrm{X}$ is amount of quercetin in $\mu \mathrm{g}$. Values were determined in mg quercetin equivalents $(\mathrm{QE})$ per g dry plant extract. The total flavonoid content of GA was $9.31 \pm 0.40 \mathrm{mg} Q E / g$ dry plant extract.

\section{DPPH radical scavenging activity}

Free radical scavenging activity of an aqueous extract GA was determined using DPPH. The activity was determined over a range of concentrations $(62.5 \mu \mathrm{g} / \mathrm{mL}$ to $1000 \mu \mathrm{g} / \mathrm{mL}$ ), and results (Figure 1) showed that the free radical scavenging activity was dose dependent, and at the highest concentration investigated the free radical scavenging activity was about $72.29 \%$. The $\mathrm{IC}_{50}$ values, the concentrations giving $50 \%$ inhibition of DPPH for GA and ascorbic acid were $628.85 \pm 32.67$ $\mu \mathrm{g} / \mathrm{mL}$ and $62.22 \pm 0.67 \mu \mathrm{g} / \mathrm{mL}$, respectively.

\section{ABTS.+ radical scavenging activity}

Free radical scavenging activity of an aqueous extract GA was additionally determined using $\mathrm{ABTS}^{+}$, using the same range of concentrations $(62.5 \mu \mathrm{g} / \mathrm{mL}$ to $1000 \mu \mathrm{g} / \mathrm{mL})$. The results (Figure 2) again showed a dose dependent inhibition of free radicals, with maximal inhibition $(97.00 \%)$ at $1000 \mu \mathrm{g} / \mathrm{mL}$, compared to $93.75 \%$ for ascorbic acid $(12.5 \mu \mathrm{g} / \mathrm{mL})$. The $\mathrm{IC}_{50}$ of ascorbic acid was $6.27 \pm 0.19 \mu \mathrm{g} /$ $\mathrm{mL}$ while that of GA was $321.41 \pm 12.76 \mu \mathrm{g} / \mathrm{mL}$.

\section{Effect of GA on mushroom tyrosinase activity}

To determine the anti-tyrosinase activity of the GA extract, a mushroom tyrosinase activity assay was performed using L-DOPA as a substrate. The results (Figure 3 ) showed that GA extract at concentrations of 7.81-1000 $\mu \mathrm{g} / \mathrm{mL}$ significantly inhibited mushroom tyrosinase activity in a dose-dependent manner $(P<0.001)$ when compared with the negative (untreated with GA) control. Kojic acid $(50 \mu \mathrm{g} / \mathrm{mL})$ as a positive control significantly $(P<0.001)$ decreased mushroom tyrosinase activity. The $\mathrm{IC}_{50}$ of GA extract was $40.72 \pm 1.83$ $\mu \mathrm{g} / \mathrm{mL}$, while that of kojic acid was $8.00 \pm 0.47 \mu \mathrm{g} / \mathrm{mL}$.

\section{Effect of GA extract on cell viability}

To determine the effect of GA on cell viability, B16F10 were seeded and after $24 \mathrm{~h}$, the cells were untreated or treated with $1 \mu \mathrm{M}$ a-MSH alone, or with $1 \mu \mathrm{M} \alpha$-MSH and GA extract or kojic acid for $48 \mathrm{~h}$, after which viability was determined using the MTT assay. Results (Figure 4) showed that the cell viability was not significantly affected by treatment with $1 \mu \mathrm{M} \alpha-\mathrm{MSH}$ when compared to control group (untreated cells). Markedly however, significant cytotoxicity was observed in cells treated with GA at concentrations of $250 \mu \mathrm{g} / \mathrm{mL}$ and above. Therefore, three

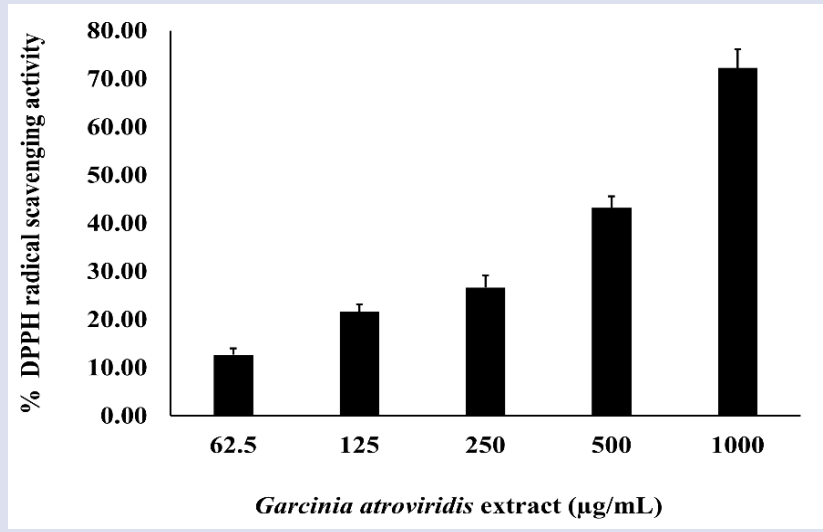

Figure 1: Scavenging activity of an aqueous extract of $G A$ as determined by DPPH assay. Each bar represents the mean of three replicates with the standard error of the means.

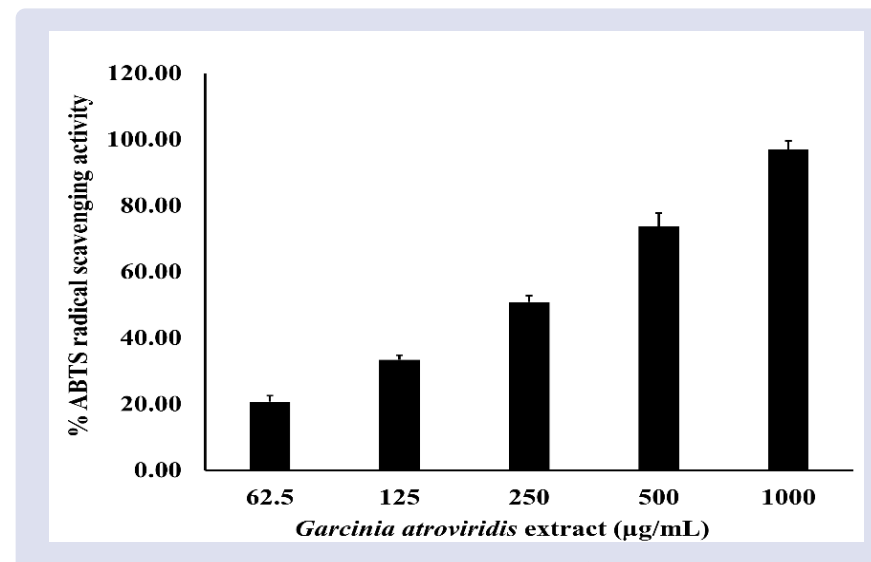

Figure 2: ABTS radical scavenging activity of GA extract. Values are mean \pm SEM of three replicates. 


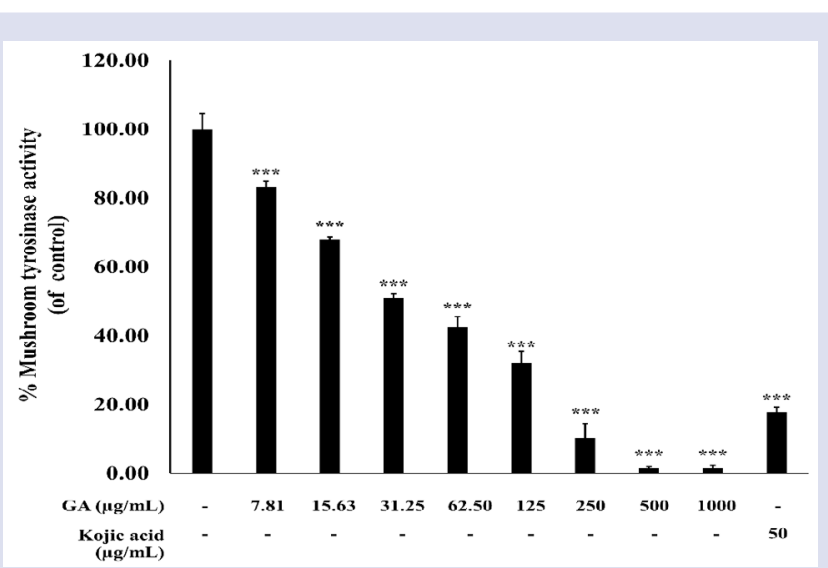

Figure 3: Effect of GA extract on mushroom tyrosinase activity. Data are mean \pm SEM of three independent replicates. ${ }^{* *} P<0.01$ as compared to control (untreated) group.

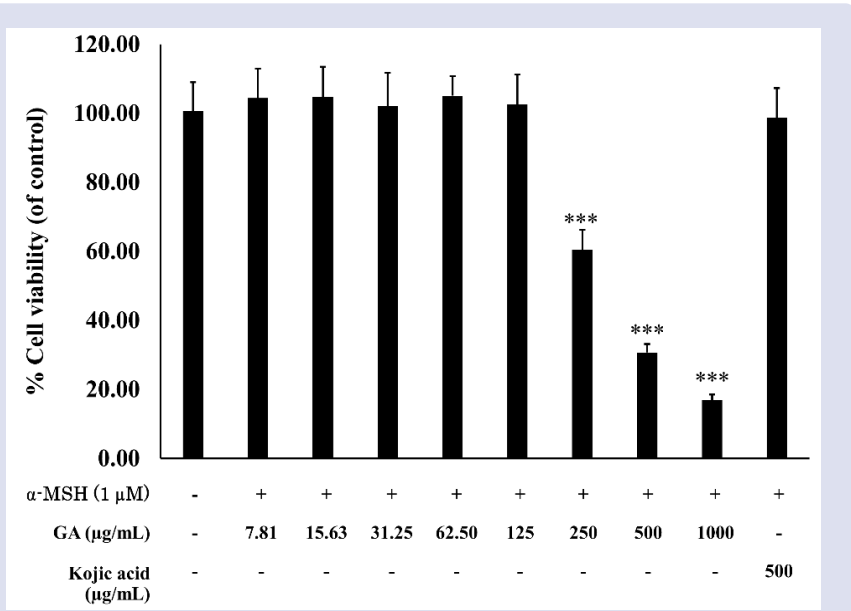

Figure 4: Effect of GA extract on cell viability. Data are presented as mean \pm SEM $(n=3)$ and expressed as \% cell viability compared to the control group. ${ }^{* *} P<0.001$ as compared to control group.

non-cytotoxic concentrations $(31.25-125 \mu \mathrm{g} / \mathrm{mL})$ were selected for further experiments.

\section{Effect of GA on cellular tyrosinase activity in a-MSH- stimulated B16F10 cells}

To determine the effect of GA on cellular tyrosinase activity, B16F10 were seeded and after $24 \mathrm{~h}$, the cells were untreated or treated with $1 \mu \mathrm{M} \alpha$-MSH alone, or with $1 \mu \mathrm{M} \alpha$-MSH and GA at three different non-cytotoxic concentrations or with kojic acid for $48 \mathrm{~h}$, after which cellular tyrosinase activity was determined by evaluating the oxidation of L-DOPA to dopachrome. The results (Figure 5a) showed that a-MSH significantly increased the cellular tyrosinase activity when compared to untreated cells (without treatment). Kojic acid as a positive control significantly inhibited the cellular tyrosinase activity $(P$ $<0.001)$ as compared to cells treated with $\alpha-\mathrm{MSH}$ only. GA extract at a concentration of $125 \mu \mathrm{g} / \mathrm{mL}$ significantly inhibited cellular tyrosinase, albeit it less effectively than kojic acid. These results suggest that GA extract can inhibit the cellular tyrosinase activity which may lead to suppress cellular melanin content in B16F10 cells.

\section{Effect of GA extract on cellular melanin content in a-MSH-stimulated B16F10 cells}

To evaluate the inhibitory effect of GA extract on melanin synthesis, we determined the melanin content of $\alpha$-MSH-stimulated B16F10 cells at
$48 \mathrm{~h}$ after treatment with various concentrations of the extract (31.25$125 \mu \mathrm{g} / \mathrm{mL})$, or with kojic acid $(500 \mu \mathrm{g} / \mathrm{mL})$. As shown in Figure 5b, a-MSH-stimulated B16F10 cells significantly $(P<0.001)$ increased melanin content when compared to untreated cells. The melanin content of $\alpha-\mathrm{MSH}$-stimulated $\mathrm{B} 16 \mathrm{~F} 10$ cells treated with GA was significantly reduced in a concentration dependent manner. Compared to control cells (treated with a-MSH only), the melanin content of cells treated with kojic acid or the maximum concentration of GA tested $(125 \mu \mathrm{g} /$ $\mathrm{mL}$ ) was reduced to $46.94 \%$ and $46.96 \%$, respectively. These results indicate that GA treatment significantly reduced melanin content in of a-MSH-stimulated B16F10 cells.

\section{Correlation between mushroom tyrosinase inhibition and free radical scavenging activity}

At concentrations of $62.5-500 \mu \mathrm{g} / \mathrm{mL}$ GA, there was a high correlation of mushroom tyrosinase inhibition with DPPH (correlation coefficient $\mathrm{R}^{2}=0.8673$; Figure 6a). Similarly, a high correlation was also found between ABTS radical scavenging activity and mushroom tyrosinase inhibition $\left(\mathrm{R}^{2}=0.9468\right.$; Figure $\left.6 \mathrm{~b}\right)$. These findings suggest that $\mathrm{DPPH}$ and ABTS scavenging activity of GA extract enhanced the inhibition of mushroom tyrosinase activity.

\section{DISCUSSION}

Garcinia atroviridis Griff. Ex. T. Anderson is commonly found in India, Malaysia and Thailand, and a number of compounds including bioflavonoids, benzophenones and xanthones are found in members of the Garcinia genus. ${ }^{24}$ In Garcinia atroviridis fruit, a number of organic acids including hydroxycitric acid (HCA), citric acid, malic acid and tartaric acid have been identified. ${ }^{25}$ Generally, dietary plants contain large amount of polyphenols such as phenolic acid, flavonoids, tannin, curcuminoids, coumarins, quinones and other compounds. ${ }^{26}$ Some phenolic and flavonoid compounds including hydroquinone, arbutin, vanillin, resorcinols, hydroxycinnamic acid, quercetin and kaemferol have been reported to be mushroom tyrosinase inhibitors and to inhibit melanogenesis. ${ }^{27,28}$ In this study, we selected the fruit pericarp of Garcinia atroviridis fruits, which were extracted with distilled water at high temperature $\left(105^{\circ} \mathrm{C}\right)$ for $1 \mathrm{~h}$. We investigated the total phenolic and flavonoid contents in an aqueous extract of Garcinia atroviridis (GA) fruit pericarps. Our aqueous extract of GA contained phenolic (26.33 $\pm 0.77 \mathrm{mg} \mathrm{GAE} / \mathrm{g}$ dry plant) and flavonoid $(9.31 \pm 0.40 \mathrm{mg} \mathrm{QE} / \mathrm{g}$ dry plant) contents. In a previous study, the total phenolic content of an aqueous extract of Garcinia atroviridis fruit extracted with distilled water at $100^{\circ} \mathrm{C}$ was higher than an aqueous extract distilled at $40^{\circ} \mathrm{C} .^{29}$

Ultraviolet radiation (UV) is an environmental factor which stimulates the production of reactive oxygen species (ROS).$^{30}$ Accumulation of ROS in skin cells can induce skin injury, hyperpigmentation, skin aging and oxidative stress. ${ }^{3}$ Antioxidants from plants might be an alternative strategy against ROS induced skin aging and hyperpigmentation. ${ }^{31}$ Therefore, we investigated the free radical scavenging activity of GA by DPPH and ABTS assays. The results showed that the scavenging activities of DPPH and ABTS ${ }^{+}$radicals by GA were dose dependent, and that the scavenging activities of the GA extract at a concentration of $1000 \mu \mathrm{g} / \mathrm{mL}$ was $72.29 \%$ and $97.00 \%$, respectively. Previous studies have shown that aqueous, methanol and ethanol extracts of Garcinia atroviridis had high antioxidant effect in scavenging DPPH and ABTS ${ }^{+}$ radicals. ${ }^{16,21,32}$ The increased phenolic contents of Garcinia atroviridis fruits were proportional to the high antioxidant activities by the DPPH assay. ${ }^{29}$ These finding suggest that the phenolic or flavonoid content is the major compound for antioxidant activities which might defend against oxidants or ROS from ultraviolet radiation.

Skin pigmentation is caused by ultraviolet radiation which stimulates the secretion of $\alpha$-melanocyte stimulating hormone ( $\alpha-M S H)$ by keratinocytes. ${ }^{33}$ With long exposure to UV, UV activates the increased 

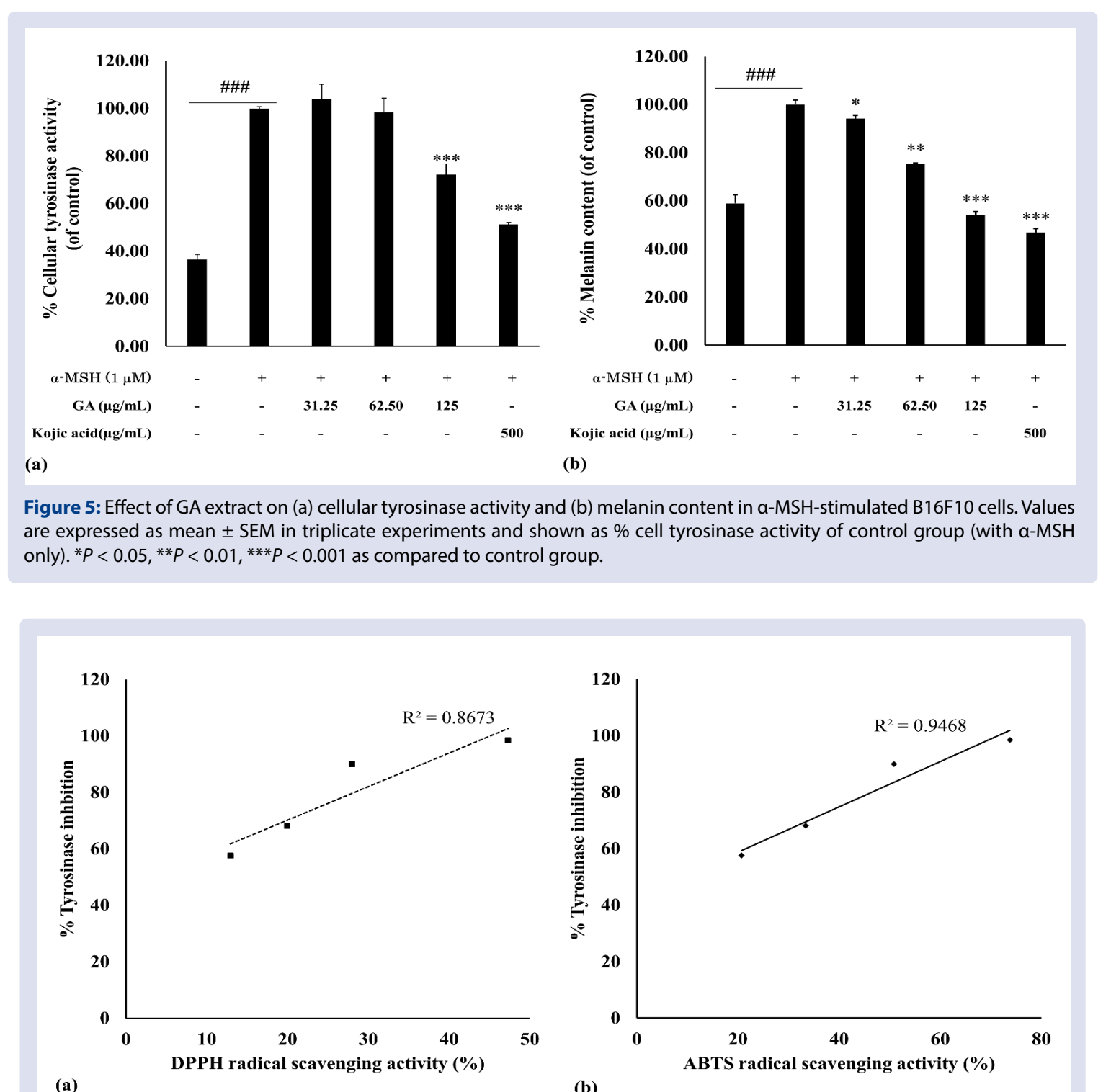

Figure 6: Correlations between mushroom tyrosinase inhibition and free radical scavenging activity including (a) DPPH radical scavenging activity and (b) ABTS radical scavenging activity.

production of a-MSH which increases melanin synthesis through upregulation of tyrosinase activity. ${ }^{34}$ Many researchers are interested in natural products to find new potent tyrosinase inhibitor for cosmetics and hyperpigmentation disorders, and many compounds from plants are key sources for tyrosinase inhibitors. In this study, we found that an aqueous extract GA significantly inhibited mushroom tyrosinase activity and cellular tyrosinase activity in $\alpha$-MSH-induced B16F10 cells. The GA extract also decreased melanin content in $a-\mathrm{MSH}$-induced B16F10 cells. Moreover, there were positive correlations between mushroom tyrosinase inhibition and free radical scavenging activity. Previous studies have reported that seedcases of Garcinia mangostana ${ }^{35}$, a hydroalcoholic leaf extract of Garcinia gadnerina ${ }^{36}$ and seeds of Garcinia kola ${ }^{37}$ significantly inhibited tyrosinase activity, but until now there was no report about tyrosinase inhibitors in extracts from Garcinia atroviridis. Our finding showed that an aqueous extract of Garcinia atroviridis fruit pericarps had significant phenolic and flavonoid contents, antioxidant activity, and antityrosinase activity, and that GA extract has the potential for development as an alternative skin whitening agent.

\section{CONCLUSION}

In this study, we have shown that an aqueous extract of Garcinia atroviridis fruit pericarps (GA) can inhibit melanin synthesis and tyrosinase activity through its antioxidant properties. GA extract contains phenolic and flavonoid compounds which are beneficial for health and disease treatment or prevention, and in cosmetic formulations. GA extract has the potential to be an alternative whitening agent for treating hyperpigmentation. Future studies aim to identify the major active compounds with tyrosinase inhibitory action.

\section{ACKNOWLEDGEMENT}

This research was funded by Research institute for Health Sciences, Walailak University, Grant no. WU-IRG-62-010. The author thanks the Research Excellence Center for Innovation and Health Product, Center of Excellence Research for Meliodosis (CERM) and Faculty of Allied Health Sciences, Chulalongkorn University for technical support and materials used in experiments. We would also like to thank Pannawich Thirabowonkitphithan for technical support. Finally, we are grateful 
to Professor Duncan R. Smith (Institute of Molecular Biosciences, Mahidol University) for manuscript editing.

\section{CONFLITCS OF INTEREST}

The authors declare no conflicts of interest.

\section{REFERENCES}

1. Tran TT-N, Schulman J, Fisher DE. UV and pigmentation: molecular mechanisms and social controversies. Pigment Cell Melanoma Res. 2008;21(5):509-16.

2. Brenner M, Hearing VJ. The protective role of melanin against UV damage in human skin. Photochem Photobiol. 2008;84(3):539-49.

3. Pillai S, Oresajo C, Hayward J. Ultraviolet radiation and skin aging: roles of reactive oxygen species, inflammation and protease activation, and strategies for prevention of inflammation-induced matrix degradation - a review. Int J Cosmet Sci. 2005;27(1):17-34.

4. Dong L, Wen J, Pier E, Zhang X, Zhang B, Dong F, et al. Melanocyte-stimulating hormone directly enhances UV-Induced DNA repair in keratinocytes by a xeroderma pigmentosum group A-dependent mechanism. Cancer Res. 2010;70(9):3547-56.

5. Price ER, Horstmann MA, Wells AG, Weilbaecher KN, Takemoto CM, Landis $\mathrm{MW}$, et al. alpha-Melanocyte-stimulating hormone signaling regulates expression of microphthalmia, a gene deficient in Waardenburg syndrome. $J$ Bio Chem. 1998;273(49):33042-7.

6. Bunleu S, Methin P. Anti-Tyrosinase and DPPH Radical Scavenging Activities of Selected Thai Herbal Extracts Traditionally Used as Skin Toner. Phcog J. $2015 ; 7(2)$.

7. Zuo AR, Dong HH, YuYY, Shu QL, Zheng LX, Yu XY, et al. The antityrosinase and antioxidant activities of flavonoids dominated by the number and location of phenolic hydroxyl groups. Chin Med. 2018;13:51.

8. Pillaiyar T, Manickam M, Namasivayam V. Skin whitening agents: medicinal chemistry perspective of tyrosinase inhibitors. J Enzyme Inhib Med Chem. 2017;32(1):403-25.

9. Tse TW. Hydroquinone for skin lightening: Safety profile, duration of use and when should we stop? J Dermatol Treat. 2010;21(5):272-5.

10. Sindhu C, Babitha C, Priyadarshini A, Veeraraghavan M. Exogenous ochronosis in an elderly Indian male: A case report. Pigment Int. 2019;6(1):33-6.

11. Hollinger JC, Angra K, Halder RM. Are Natural Ingredients Effective in the Management of Hyperpigmentation? A Systematic Review. J Clin Aesthet Dermatol. 2018;11(2):28-37.

12. Taher M, Hamidon H, Susanti D, Zakaria ZA. Garcinia atroviridis - A review on phytochemicals and pharmacological properties. Marmara Pharm J. 2016;21:38-47.

13. Mackeen MM, Ali AM, Lajis NH, Kawazu K, Hassan Z, Amran M, et al. Antimicrobial, antioxidant, antitumour-promoting and cytotoxic activities of different plant part extracts of Garcinia atroviridis Griff. ex T. Anders. J Ethnopharmacol. 2000;72(3):395-402.

14. Basri DF, Sharif R, Morat P, Latip J. Evaluation of antimicrobial activities of the crude extracts from Garcinia atroviridis and Solanum torvum. Mal J Sci. 2005;24(1):233-8.

15. Suwanmanee S, Kitisin T, Luplertlop N. In vitro screening of 10 edible thai plants for potential antifungal properties. Evid Based Complement Alternat Med. 2014;2014:138587.

16. Al-Mansoub MA, Asmawi MZ, Murugaiyah V. Effect of extraction solvents and plant parts used on the antihyperlipidemic and antioxidant effects of Garcinia atroviridis: a comparative study. J Sci Food Agric. 2014;94(8):1552-8.

17. Al-Mansoub MA, Asmawi MZ, Murugaiyah V. Aqueous extract of Garcinia atroviridis fruit improves oxidative status of high fat diet-induced hyperlipidemic rats. Conference Abstract: International Conference on Drug Discovery and Translational Medicine "Seizing Opportunities and Addressing Challenges of Precision Medicine"; 2019 Dec-Feb; Putrajaya, Malaysia: Frontier Pharmacol; 2019.
18. Ali Hassan SH, Fry JR, Abu Bakar MF. Phytochemicals Content, Antioxidant Activity and Acetylcholinesterase Inhibition Properties of Indigenous Garcinia parvifolia Fruit. BioMed Res Int. 2013;2013:7

19. Chatatikun M, Chiabchalard $A$. Thai plants with high antioxidant levels, free radical scavenging activity, anti-tyrosinase and anti-collagenase activity. BMC Complement Altern Med. 2017;17(1):487.

20. Formagio ASN, Volobuff CRF, Santiago M, Cardoso CAL, Vieira MdC, Valdevina Pereira Z. Evaluation of Antioxidant Activity, Total Flavonoids, Tannins and Phenolic Compounds in Psychotria Leaf Extracts. Antioxidants (Basel). 2014;3(4):745-57

21. Abbasi BH, Siddiquah A, Tungmunnithum D, Bose $S$, Younas $M$, Garros $L$, et al. Isodon rugosus (Wall. ex Benth.) Codd In Vitro Cultures: Establishment, Phytochemical Characterization and In Vitro Antioxidant and Anti-Aging Activities. Int J Mol Sci. 2019;20(2):452.

22. Rashid HA, Jung HY, Kim JK. Enhanced reutilization value of shrimp-shell waste via fed-batch biodegradation with higher production of reducing sugar, antioxidant, and DNA protective compounds. Fish Aquat Sci. 2018;21(1):33.

23. Eghbali-Feriz S, Taleghani A, Al-Najjar H, Emami S, Rahimi H, Asili J, et al. Anti-melanogenesis and anti-tyrosinase properties of Pistacia atlantica subsp. extracts on B16F10 murine melanoma cells. Res Pharm Sci. 2018;13(6):533-45.

24. Waterman PG, Hussain RA. Systematic significance of xanthones, benzophenones and biflavonoids in Garcinia. Biochem Syst Ecol. 1983;11(1):218 .

25. Jayaprakasha GK, Sakariah KK Determination of (-) hydroxycitric acid in commercial samples of Garcinia cambogia extract by liquid chromatography with ultraviolet detection. J Liq Chrom Relat Tech. 2000;23(6):915-23.

26. Huang WY, Cai YZ, Zhang Y. Natural phenolic compounds from medicinal herbs and dietary plants: potential use for cancer prevention. Nutr Cancer 2010;62(1):1-20.

27. Zolghadri S, Bahrami A, Hassan Khan MT, Munoz-Munoz J, Garcia-Molina F, Garcia-Canovas F, et al. A comprehensive review on tyrosinase inhibitors. J Enzyme Inhib Med Chem. 2019;34(1):279-309.

28. Panzella L, Napolitano A. Natural and Bioinspired Phenolic Compounds as Tyrosinase Inhibitors for the Treatment of Skin Hyperpigmentation: Recent Advances. Cosmetics. 2019;6(4):57.

29. Nursakinah I, Zulkhairi HA, Norhafizah M, Hasnah B, Zamree MS, Farrah SI, et al. Nutritional content and in vitro antioxidant potential of Garcinia atroviridis (Asam gelugor) leaves and fruits. Malays J Nutr. 2012;18(3):363-71.

30. de Jager TL, Cockrell AE, Du Plessis SS. Ultraviolet light induced generation of reactive oxygen species. Adv Exp Med Biol. 2017;996:15-23.

31. Petruk G, Del Giudice R, Rigano MM, Monti DM. Antioxidants from Plants Protect against Skin Photoaging. Oxid Med Cell Longev. 2018;2018:1454936.

32. Jamila N, Khan N, Hwang IM, Nho EY, Choi JY, Atlas A, et al. Application of Phytochemical and Elemental Profiling, Chemometric Multivariate Analyses, and Biological Activities for Characterization and Discrimination of Fruits of Four Garcinia Species. Anal Lett. 2019:1-18.

33. Cui R, Widlund HR, Feige E, Lin JY, Wilensky DL, Igras VE, et al. Central role of p53 in the suntan response and pathologic hyperpigmentation. Cell. 2007; 128(5):853-64.

34. Tsatmali M, Ancans J, Thody AJ. Melanocyte Function and Its Control by Melanocortin Peptides. J Histochem Cytochem. 2002;50(2):125-33.

35. Ryu HW, Jeong SH, Curtis-Long MJ, Jung S, Lee JW, Woo HS, et al. Inhibition effects of mangosenone $F$ from Garcinia mangostana on melanin formation in B16F10 cells. J Agric Food Chem. 2012;60(34):8372-8.

36. Campos PM, Horinouchi CDdS, Prudente AdS, Cechinel-Filho V, Cabrini DdA, Otuki MF. Effect of a Garcinia gardneriana (Planchon and Triana) Zappi hydroalcoholic extract on melanogenesis in B16F10 melanoma cells. J Ethnopharmacol. 2013;148(1):199-204.

37. Okunji C, Komarnytsky S, Fear G, Poulev A, Ribnicky DM, Awachie PI, et al Preparative isolation and identification of tyrosinase inhibitors from the seeds of Garcinia kola by high-speed counter-current chromatography. J Chromatogr A. $2007 ; 1151(1-2): 45-50$. 


\section{GRAPHICAL ABSTRACT}

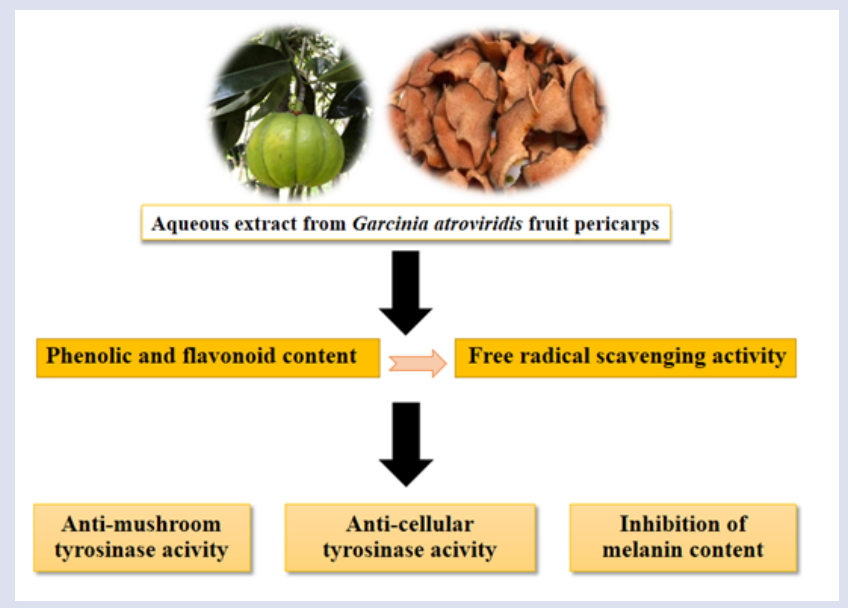

\section{SUMMARY}

- Aqueous extract of Garcinia atroviridis fruit pericarps had phenolic and flavonoid contents which scavenge DPPH and ABTS free radicals.

- The aqueous extract of Garcinia atroviridis significantly inhibited both mushroom tyrosinase activity and cellular tyrosinase activity in $\alpha$-MSH-induced B16F10 cells.

- The aqueous extract of Garcinia atroviridis also suppressed melanin content in $\alpha$-MSH-induced B16F10 cells.

- In a correlative study, there was high correlation between mushroom tyrosinase inhibition and free radical scavenging activity (DPPH and ABTS radicals).

\section{ABOUT AUTHORS}

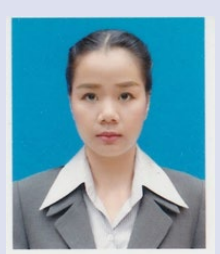

Dr.Moragot Chatatikun: Lecturer at Department of Medical Technology, School of Allied Health Sciences, Walailak University, Thailand.

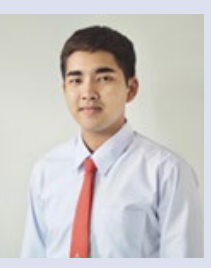

Pitaksit Supjaroen: Undergraduate student at Department of Medical Technology, School of Allied Health Sciences, Walailak University, Thailand.

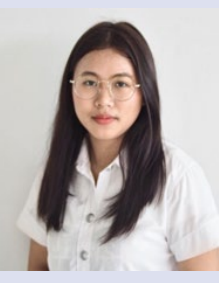

Patcharaporn Promlat: Undergraduate student at Department of Medical Technology, School of Allied Health Sciences, Walailak University, Thailand

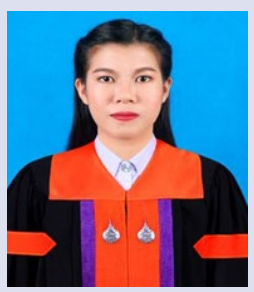

Chantanapa Chantarangkul: Undergraduate student at Department of Medical Technology, School of Allied Health Sciences, Walailak University, Thailand.

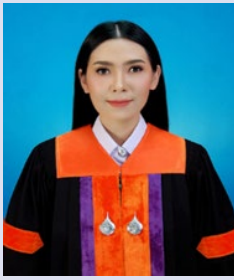

Sutida Waranuntakul: Undergraduate student at Department of Medical Technology, School of Allied Health Sciences, Walailak University, Thailand. 


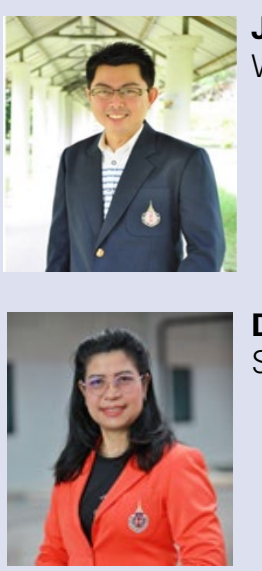

Jiraphat Nawarat: Assistant Professor at Department of Physical Therapy, School of Allied Health Sciences, Walailak University, Thailand.

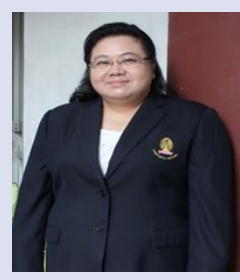

Dr.Anchalee Chiabchalard: Assistant Professor at Department of Clinical Chemistry, Faculty of Allied Health Sciences, Chulalongkorn University, Thailand.

Cite this article: Chatatikun M, Supjaroen P, Promlat P, Chantarangkul C, Waranuntakul S, Nawarat J, et al. Antioxidant and Tyrosinase Inhibitory Properties of an Aqueous Extract of Garcinia atroviridis Griff. ex. T. Anderson Fruit Pericarps. Pharmacog J. 2020;12(1):71-8. 